\title{
The Relationship of Parenting Style and Perception of Sexuality, Gender and Norm of Reproductive Health among Adolescents
}

\author{
Eka Aprilia Wulandari, ${ }^{1}$ \\ Tantut Susanto, ${ }^{2}$ Kholid \\ Rosyidi Muhammad Nur ${ }^{3}$ \\ 1,2,3 Faculty of Nursing, Universitas Jember, \\ Jember-Indonesia
}

Corresponding Author: Tantut Susanto, email: tantut_s.psik@unej.ac.id, Kampus Tegalboto, J. Kalimantan No. 37, Krajan Timur, Sumbersari, Sumbersari, Jember, Jawa Timur 68121

\begin{abstract}
Parenting is an interaction between children and parents, including fulfilling physical, psychological needs, and socializing norms in society. The results of the adaptation of parenting styles include sexuality, gender, and norm perception (SGNP) in adolescent reproductive health. This study aims to analyze the relationship between parenting style with SGNP in adolescent reproductive health in Patrang District, Jember Regency. This study was a correlational analytic with a crosssectional approach conducted among 158 participants with a cluster random sampling technique. Data collection used a questionnaire to identify the characteristics of participants, parenting with Parenting Style Dimension Questionnaire (PSDQ), and SGNP in adolescent reproductive health with Sexuality, Gender, and Norms Questionnaire. Spearman Rank Correlation as an analysis method was used to answer the objectives of this study. Among 158 participants, 65.8\% were authoritative parenting, $20.9 \%$ were authoritarian and $13.3 \%$ were permissive. Besides, $53.2 \%$ of adolescents had positive of SGNP in reproductive health. There is a relationship between parenting style and SGNP in adolescent reproductive health $(\mathrm{r}=0.193 ; \mathrm{p}=$ 0.015 ). Therefore, a planned intervention is needed such as educating parents and adolescents to be able to apply proper parenting to form positive perceptions.
\end{abstract}

Keywords: adolescent; reproductive health; parenting; sexuality; gender perception; norm

Abstrak: Pola asuh orang tua merupakan interaksi anak dengan orang tua meliputi pemenuhan kebutuhan fisik, psikologis dan sosialisasi norma-norma di masyarakat. Hasil dari adaptasi pola asuh orang tua salah satunya adalah persepsi gender, perilaku dan norma (SGNP) dalam kesehatan reproduksi remaja. Interaksi anak dengan orang tua dapat membentuk karakter, kepribadian dan persepsi mereka khususnya terhadap kesehatan reproduksi. Persepsi tersebut dapat mengarah ke hal positif maupun negatif. Studi ini bertujuan menganalisis hubungan antara pola asuh orang tua dengan persepsi gender, perilaku dan norma dalam kesehatan reproduksi remaja di Kecamatan Patrang Kabupaten Jember. Penelitian ini merupakan analitik korelasional dengan pendekatan cross-sectional yang dilakukan pada 158 partisipan dengan menggunakan teknik cluster random sampling. Pengumpulan data menggunakan kuesioner untuk mengidentifikasi karakteristik partisipan, pola asuh orang tua 
dengan Parenting Style Dimension Questionnaire (PSDQ) dan SGNP dalam kesehatan reproduksi remaja dengan Sexuality, Gender and Norms Questionnaire. Spearman Rank Correlation sebagai metode analisis digunakan untuk menjawab tujuan dari studi ini. Dari 158 partisipan, teridentifikasi 65,8\% pola asuh otoritatif, $20,9 \%$ otoriter dan $13,3 \%$ permisif. Selain itu, $53,2 \%$ remaja memiliki SGNP dalam kesehatan reproduksi positif. Terdapat hubungan antara pola asuh orang tua dengan SGNP dalam kesehatan reproduksi remaja $(\mathrm{r}=0,193 ; p$ $=0,015)$. Oleh karena itu, diperlukan intervensi terencana seperti edukasi kepada orang tua dan remaja agar dapat menerapkan pola asuh yang tepat agar terbentuk persepsi yang positif.

Kata Kunci: remaja; kesehatan reproduksi, pola asuh orang tua; persepsi gender; perilaku; norma

\section{A. Introduction}

As many as $35 \%$ of women of various ages have experienced sexual violence, ${ }^{1}$ this rate is greater than men where women receive more negative impacts. $^{2}$ It turns out that violence appears most often in adolescents. ${ }^{3}$ Adolescents in their development must still be supervised by parents, so parenting parents play a role in shaping and controlling adolescent behavior. ${ }^{4}$ Adolescent behavior is based on gender and traditional norms resulting from the quality of parental care. ${ }^{5}$ Therefore, if parents can provide good care, it is expected that adolescents will understand their gender and will carry out gender roles well and there is no higher gender between the two.

\footnotetext{
${ }^{1}$ World Health Organization, "Global Health Observatory (GHO) Data: Violence Against Women," World Health Organization, 2015, 1-2, https://www.who.int/gho/women_and_health/ violence/en/.

${ }^{2}$ M. C. Black et al., The National Intimate Partner and Sexual Violence Survey: 2010 Summary Report (Atlanta, GA: National Center for Injury Prevention and Control, Centers for Disease Control and Prevention, 2011), 18-19.

${ }^{3}$ World Health Organization, "Adolescents: Health Risks and Solutions," World Health Organization, 2018, 1-2, https://www.who.int/news-room/fact-sheets/detail/adolescents-healthrisks-and-solutions.

${ }^{4}$ Akanksha Mohta, Prasanta Kumar Roy, and Pradeep Kumar Saha, “A Study on Perceived Parenting Style among Transgender," Open Journal of Psychiatry \& Allied Sciences 8, no. 2 (2017): 157, https://doi.org/10.5958/2394-2061.2017.00014.3.

${ }^{5}$ Leodoro J. Labrague et al., "Future Educators' Gender Norms, Sexuality, and Reproductive Health," Online Journal of Health and Allied Sciences 11, no. 4 (2012): 1-6; Daphne van de Bongardt et al., "Parents as Moderators of Longitudinal Associations Between Sexual Peer Norms and Dutch Adolescents' Sexual Initiation and Intention," Journal of Adolescent Health 55, no. 3 (September 2014): 388-93, https://doi.org/10.1016/j.jadohealth.2014.02.017.
} 
Inappropriate gender norms often lead to risky sexual behavior.6 ${ }^{6}$ This is based on adolescent perceptions, where it is obtained through their knowledge from friends, social media, and parents.7 If the perception of adolescents is positive, it means that it will influence teens not to engage in risky sexual behavior. An adequate form of parenting can give birth to gender power and positive cultural norms of sexuality such as reducing male superiority and sexual decision making for women without coercion. ${ }^{8}$

Gender is recognized as a social conditioning and a major social determinant of reproductive health, ${ }^{9}$ which shapes perceptions of gender attitudes as boys and girls. Gender socialization began from the time the baby was born into the world, at that time sex socialization began. Structural factors such as social norms that shape individual perceptions of sexual behavior enable men to engage in greater sexual behavior than women.10 Adolescent Reproductive Health Problems (KRR) in Jember District shows the prevalence that adolescent boys behave more negatively towards reproductive health (56.6\%) compared to adolescent girls (43.7\%). ${ }^{11}$

The family is the first learning medium for teenagers and as the smallest social group in society. Hurlock in Maryatun and Hidayah states that the role of parents is very important in the child's growth and development processes such as children's confidence, ability to interact, and subsequently leads to

\footnotetext{
${ }^{6}$ Labrague et al., "Future Educators' Gender Norms, Sexuality, and Reproductive Health.”

${ }^{7}$ Titik Sumiatin, Hadi Purwanto, and Wahyu Tri Ningsih, "Pengaruh Persepsi Remaja tentang Perilaku Seks terhadap Niat Remaja dalam Melakukan Perilaku Seks Beresiko," Jurnal Keperawatan 8, no. 1 (2017): 96-101.

${ }^{8}$ Joyce Wamoyi, Daniel Wight, and Pieter Remes, "The Structural Influence of Family and Parenting on Young People's Sexual and Reproductive Health in Rural Northern Tanzania," Culture, Health \& Sexuality 17, no. 6 (2015): 718-32, https://doi.org/10.1080/13691058.2014.992044.

${ }^{9}$ LA Rolleri, “Gender Norms and Sexual Health Behaviors," Research FACTS and Findings., 2013, 1-7; Paul J. Fleming and Christine Agnew-Brune, "Current Trends in the Study of Gender Norms and Health Behaviors," Current Opinion in Psychology 5, no. 2 (2015): 72-77, https://doi.org/10.1016/ j.copsyc.2015.05.001.

${ }^{10}$ Eva S. Lefkowitz et al., "How Gendered Attitudes Relate to Women's and Men's Sexual Behaviors and Beliefs," Sexuality \& Culture 18, no. 4 (2014): 833-46, https://doi.org/10.1007/ s12119-014-9225-6.

${ }^{11}$ Tantut Susanto, Iis Rahmawati, and Wantiyah Wantiyah, "Pengaruh Visualisation in Participatory Program (VIPP) dan Metode Ceramah terhadap Pengetahuan, Sikap, dan Keterampilan Kesehatan Reproduksi Remaja di Jember," Jurnal Kesehatan Reproduksi 8, no. 2 (2017): 119-29, https://doi.org/10.22435/kespro.v8i2.5753.119-129.
} 
parental authority. ${ }^{12}$ Someone who lives and grew up in a democratic environment and sees that between men and women have the same rights and obligations, then they will be held that way.13 Parental care for adolescents has an impact on adolescent sexuality, gender, and norm perception (SGNP) in reproductive health. Adolescents with authoritarian parenting have the opportunity to engage in sexual behavior nineteen times greater than permissive parenting, while permissive parenting is three times more likely than authoritative parenting. ${ }^{14}$ This proves that the parenting used by every parent has an important influence on adolescent sexuality.

Based on the phenomena outlined above, the problem of this study is important to answer because until now in society there are still many who think that men are superior to women. Teenage boys are more willing to engage in risky sexual behavior than women, which may be due to the assumption that they are stronger and feel challenged. This distinction if not immediately addressed will continue to carry over to the next generation which can lead to gender disparities and have an impact on the perception that men are higher than women. It also relates to why the most disadvantaged related to reproductive health problems are women such as victims of sexual violence. Parents as the first educator for their children play an important role in controlling this to realize gender equality through the parenting provided. Then the further discussion is needed regarding parenting practices applied by each family so that adolescents have positive sexuality, gender, and norms perception in their reproductive health. Therefore, researchers are interested in examining the relationship of parenting style with sexuality, gender, and norm perception in adolescent reproductive health.

\section{B. Method}

The research design used was quantitative observational analytic research with cross-sectional approach and cluster random sampling techniques. The participants of this study were 158 families consisting of parents and children

\footnotetext{
${ }^{12}$ Maryatun Maryatun and Nurul Farimah Nurul Hidayah, "Hubungan antara Pola Asuh Orang Tua dengan Perilaku Seksual Pranikah pada Remaja di SMK Batik 1 Surakarta," Gaster: Jurnal Kesehatan 10, no. 2 (2013): 53-61.

${ }^{13}$ Maryatul Kibtyah, "Peran Konseling Keluarga dalam Menghadapi Gender dengan Segala Permasalahannya," Sawwa: Jurnal Studi Gender 9, no. 2 (2017): 361-80, https://doi.org/10.21580/ sa.v9i2.641.

${ }^{14}$ Maryatun and Hidayah, "Hubungan Antara Pola Asuh Orang Tua dengan Perilaku Seksual Pranikah pada Remaja di SMK Batik 1 Surakarta.”
} 
aged 13-19 years in Patrang District, Jember Regency. Teenagers involved are teenagers who have never been married and have not experienced mental retardation.

The data collection uses three questionnaires consisting of socio-demographic questionnaires, parenting style and sexuality, gender, and norm perception (SGNP) in adolescent reproductive health. The socio-demographic questionnaire consisted of two characteristics namely family (name, age, gender, ethnicity, father/mother's last education, father/mother's occupation, number of children, income) and adolescents (name, age, gender, last education, dating experience). The parenting style questionnaire was the Parenting Style Dimension Questionnaire (PSDQ), which was developed by Robinson based on Baumrin's parenting construction, while the SGNP questionnaire in reproductive health was published by WHO based on the development of the Illustrative Questionnaire for interviews-Surveys with Young People. ${ }^{15}$

Selected participants who meet the criteria are then explained the aims and objectives of the study, after understanding then the participants are welcome to fill out an informed consent sheet. After that, the participants filled out a socio-demographic questionnaire, parenting style and sexuality, gender, and norm perception in reproductive health. Parenting questionnaire consists of 32 items covering authoritative, authoritarian and permissive domains (five Likert scales, i.e. never $=1$, rarely $=2$, sometimes $=3$, often $=4$, always $=5$, with a range of scores from 1 to 160). The SGNP questionnaire in adolescent reproductive health consists of 21 items (three answer choices, i.e. disagree $=1$, doubtful $=2$, agree $=3$, with a range of scores from 1 to 63 ). ${ }^{16}$

The parenting questionnaire before use was carried out back translation and validity and reliability tests. The validity test was carried out through a content validity index (CVI) test involving six experts in child nursing, family nursing, and community nursing $(\alpha=0.80)$ and reliability (Cronbach's $\alpha=$

\footnotetext{
${ }^{15}$ Tantut Susanto et al., "Prevalence of Factors Related to Active Reproductive Health Behavior: A Cross-Sectional Study Indonesian Adolescent," Epidemiology and Health 38 (2016): e2016041, https://doi.org/10.4178/epih.e2016041.

${ }^{16}$ Tantut Susanto, Iis Rahmawati, and Wantiyah Wantiyah, "A Community-Based Friendly Health Clinic: An Initiative Adolescent Reproductive Health Project in the Rural and Urban Areas of Indonesia," International Journal of Nursing Sciences 3, no. 4 (2016): 371-78, https://doi.org/ 10.1016/j.jijnss.2016.11.006.
} 
0.712) used to measure the consistency of the questionnaire. The SGNP questionnaire was tested for validity and reliability by Susanto et al (2016) by modifying items following the conditions of adolescents in Indonesia. ${ }^{17}$

This research applies several ethical principles of research through informed consent that includes aspects of the explanation of the research process, including research objectives, data collection, benefits, and disadvantages of being a participant. Participants are given the right and obligation to be willing or not in research by first explaining the rights and obligations of participants and researchers. This research also considers the confidentiality aspect where the information that has been given by participants will not be accessible other than the research team. This study also received a research permit from the Team for Health Research Ethics Commission at the Faculty of Dentistry, University of Jember No. 267 / UN25.8 / KEPK / DL / 2019.

The collected data is then analyzed using descriptive analysis (frequency, percentage, mean, median, and standard deviation). First, the normality of the data was tested with Kolmogorov Smirnov, because the dependent variable of the study was not normally distributed $(\mathrm{p}<0.05)$, then the Spearman Rank Correlation was used in correlative analysis with an alpha value of $p<0.05$ to determine statistical significance.

\section{Results}

The study was conducted on 158 families consisting of parents and adolescents with the characteristics presented in Table 1. Age of parents with a middle value of 45 years, the majority of parents involved were women (72.8\%), the majority of parent education was medium and equal with $42.3 \%$ of fathers, and $37.6 \%$ of mothers. The majority of fathers work as entrepreneurs (26.2\%), while mothers as housewives (61.1\%), families have the most monthly income of $>1,000,000$ (41.1\%), the majority of families are main families $(72,2 \%)$ with more than 2 children (46.8\%) and Javanese (70.9\%). Adolescents with a middle value of 16 years, the majority are female (62.7\%) with the most recent education, namely junior high school (44.3\%) and the majority have no dating experience (62.0\%).

\footnotetext{
${ }^{17}$ Susanto et al., "Prevalence of Factors Related to Active Reproductive Health Behavior: A Cross-Sectional Study Indonesian Adolescent," 1-10.
} 
Table 1.

Participant Characteristics ( $n=158)$

\begin{tabular}{|c|c|c|}
\hline \multicolumn{2}{|c|}{ Characteristics of Parents and Adolescents } & n (\%) \\
\hline \multicolumn{2}{|c|}{ Parent's Age (Years Old). Md. (P25-P75) } & $45(39-49)$ \\
\hline \multicolumn{2}{|c|}{ Adolescents Age (Years Old). Md. (P25-P75) } & $16(14-17)$ \\
\hline \multirow[t]{2}{*}{ Parent's Gender } & Male & $43(27,2)$ \\
\hline & Female & $115(72,8)$ \\
\hline \multirow{2}{*}{ Adolescent's Gender } & Male & $59(37,3)$ \\
\hline & Female & $99(62,7)$ \\
\hline \multirow[t]{5}{*}{ Father's Last Education } & Unfinished Elementary School/No School & $7(3,4)$ \\
\hline & Elementary School & $43(27,5)$ \\
\hline & Junior High School & $25(15,4)$ \\
\hline & Senior High School & $65(42,3)$ \\
\hline & College & $18(11,4)$ \\
\hline \multirow[t]{5}{*}{ Mother's Last Education } & Unfinished Elementary School/No School & $11(6,4)$ \\
\hline & Elementary School & $51(32,5)$ \\
\hline & Junior High School & $21(13,4)$ \\
\hline & Senior High School & $59(37,6)$ \\
\hline & Colege & $16(10,2)$ \\
\hline \multirow[t]{3}{*}{ Adolescent's Last Education } & Elementary School & $61(38,6)$ \\
\hline & Junior High School & $70(44,3)$ \\
\hline & Senior High School & $27(17,1)$ \\
\hline \multirow[t]{7}{*}{ Father's Occupation } & Laborer & $32(20,1)$ \\
\hline & Farmer & $8(3,4)$ \\
\hline & Private Employee & $23(14,8)$ \\
\hline & Government Employee & $20(12,8)$ \\
\hline & Enterpreneur & $40(26,2)$ \\
\hline & Unemployed & $7(4,0)$ \\
\hline & Other & $28(18,8)$ \\
\hline \multirow[t]{7}{*}{ Mother's Occupation } & Laborer & $6(3,8)$ \\
\hline & Farmer & $3(1,3)$ \\
\hline & Private Employee & $10(6,4)$ \\
\hline & Government Employee & $10(6,4)$ \\
\hline & Entrepreneur & $14(8,9)$ \\
\hline & Housewife & $96(61,1)$ \\
\hline & Other & $19(12,1)$ \\
\hline \multirow[t]{3}{*}{ Family Income } & $<500.000,-$ & $33(20,9)$ \\
\hline & 500.000-1.000.000,- & $60(38,0)$ \\
\hline & $>1.000 .000,-$ & $65(41,1)$ \\
\hline \multirow[t]{2}{*}{ Family Type } & Main Family & $114(72,2)$ \\
\hline & Extended Family & $44(27,8)$ \\
\hline \multirow[t]{3}{*}{ Number of Children } & 1 & $12(7,6)$ \\
\hline & 2 & $72(45,6)$ \\
\hline & $>2$ & $74(46,8)$ \\
\hline \multirow[t]{2}{*}{ Ethnic } & Javanese & $112(70,9)$ \\
\hline & Maduranese & $46(29,1)$ \\
\hline \multirow[t]{2}{*}{ Dating Experience } & Yes & $60(38,0)$ \\
\hline & No & $98(62,0)$ \\
\hline
\end{tabular}

Note: $\mathrm{n}(\%)=$ Number of participants (percentage); $M d=$ Median; $($ P25-P75) = Percentiles 25-75 
Eka Aprilia Wulandari, Tantut Susanto, Kholid Rosyidi Muhammad Nur

Table 2 shows the distribution of parenting patterns in Patrang District and it can be seen that parenting patterns in Patrang District have the largest average in authoritative parenting (3.90 \pm 0.67 ), so parents in Patrang District tend to apply the pattern authoritative foster care in his family (65.8\%).

Table 3 shows the distribution of sexuality, gender, and norm perception (SGNP) in adolescent reproductive health in Patrang District. Based on Table 3 it is known that the middle value of SGNP in adolescent reproductive health is 49 with percentiles 25-75 of 45 to 52, then Kolmogorov Smirnov's calculated value shows 1.51 with a p-value of 0.02 and the highest category is positive perception (53.2\%).

Table 2.

Distribution of Parenting Parents in Patrang District

\begin{tabular}{ccc}
\hline \multicolumn{1}{c}{ Parenting Style } & Mean \pm SD & n (\%) \\
\hline Score Value & & \\
Authoritative(democratic) & $3,90 \pm 0,67$ & \\
Authoritative (authoritarian) & $2,45 \pm 0,61$ & \\
Permissive & $2,13 \pm 0,84$ & $104(65,8)$ \\
Proportion of Parenting & & $33(20,9)$ \\
Authoritative(democratic) & & $21(13,3)$ \\
$\quad$ Authoritative (authoritarian) & & $158(100)$ \\
\hline Permissive & & \\
\hline
\end{tabular}

Note: $\mathrm{n}(\%)=$ Number of participants (percentage)

Table 3.

Distribution of Gender Perception, Behavior and Norms in Adolescent Reproductive Health in Patrang District

\begin{tabular}{|c|c|c|c|c|}
\hline $\begin{array}{l}\text { Gender Perception, } \\
\text { Behavior, and Norms }\end{array}$ & n (\%) & $\operatorname{Md}\left(P_{25}-P_{75}\right)$ & K-S & p-value \\
\hline Total Score & & $49(45-52)$ & 1,51 & $0,02^{a}$ \\
\hline \multicolumn{5}{|l|}{ Category } \\
\hline Positive & $84(53,2)$ & & & \\
\hline Negative & $74(46,8)$ & & & \\
\hline
\end{tabular}

Note: Md = Median; P25-P75 = Percentiles 25-75; K-S = Calculated Value Kolmogorov-Smirnov test; $a=$ Significant Kolmogorov-Smirnovtest 
Table 4.

Relationship of Parenting Parenting with Gender Perception, Behavior and Norms in Adolescent Reproductive Health in Patrang District $(n=158)$

\begin{tabular}{lcc}
\hline Parenting Style & $\begin{array}{c}\text { Gender Perception, Behavior, and Norms in } \\
\text { Adolescent Reproductive Health }\end{array}$ \\
\cline { 2 - 3 } & $\boldsymbol{r}$ & $\boldsymbol{p}$-value \\
\hline Authoritative(democratic) & 0,171 & 0,031 \\
Authoritative (authoritarian) & 0,018 & 0,819 \\
Permissive & 0,142 & 0,075 \\
Parenting Total Score & 0,193 & 0,015 \\
\hline
\end{tabular}

Note: $r=$ Correlation coefficient

Table 4 shows that there is a relationship between parenting style and SGNP in adolescent reproductive health analyzed using total parenting scores ( $\mathrm{r}$ $=0.193 ; p=0.015$ ) and also shows for authoritative categories related to SGNP in reproductive health $(\mathrm{r}=0.171 ; \mathrm{p}=0.031)$, but the authoritarian and permissive categories are not related ( $\mathrm{p}>0.05)$.

\section{Discussion}

Based on the results of the research that has been obtained can be seen that there is a relationship between parenting parents with gender perceptions, behaviors, and norms in adolescent reproductive health in Patrang District, Jember Regency. In line with research Bongardt, et al ${ }^{18}$ stated that good parenting quality is associated with sexual behavior in adolescents. The behavior is based on adolescent perceptions on each gender and if adolescent perceptions are positive then it affects adolescents not to engage in risky sexual behavior. ${ }^{19}$ The application of parental care needs to be considered so that it can create positive child behavior towards the SGNP in adolescent reproductive health. If parents can apply appropriate parenting, children can have positive perceptions of reproductive health.

\footnotetext{
${ }^{18}$ van de Bongardt et al., "Parents as Moderators of Longitudinal Associations Between Sexual Peer Norms and Dutch Adolescents' Sexual Initiation and Intention."

${ }^{19}$ Sumiatin, Purwanto, and Ningsih, "Pengaruh Persepsi Remaja tentang Perilaku Seks terhadap Niat Remaja dalam Melakukan Perilaku Seks Beresiko."
} 
The tendency of parenting in Patrang District is authoritative parenting $65.8 \%$. This research is related to the research of Lin and Billingham ${ }^{20}$ that parents who tend to authoritatively nurture by sharing the same gender roles between masculinity and femininity so that there are no gaps and positive gender perceptions. In this study, some parents tended to have authoritative parenting (65.8\%) and most of their teens had gender perceptions, behaviors, and norms in positive reproductive health (53.2\%). According to Hurlock (2007) in Maryatun and Hidayah ${ }^{21}$ it is related to sociodemography such as age, sex, education, socioeconomic, and situation. In the results of the study note that the age of most parents is 45 years, the most recent education of parents is a Senior High School (79.9\%), so researchers assume that parents in middle adulthood development will tend to apply authoritative parenting and the higher the level of parental education, it will increasingly understand the parenting that is applied to produce positive teenage perceptions.

Effective parenting involves the conditions of the socio-cultural environment and education level, ${ }^{22}$ the higher the level of education the more authoritative parents will be..$^{23}$ There are two cultures identified in this study, namely Java and Madura. Differences are also seen in filling out the questionnaire that families with Javanese culture always give freedom of participation to children, another case with Madura culture which rarely provides freedom of participation. The level of education also shows that at the highest level, namely college, parents are more likely to be authoritative. Based on that, Javanese

${ }^{20}$ Yi-Ching Lin and Robert E. Billingham, “Relationship between Parenting Styles and Gender Role Identity in College Students," Psychological Reports 114, no. 1 (2014): 250-71, https://doi.org/10.2466/21.09.PR0.114k13w4.

${ }^{21}$ Maryatun and Hidayah, "Hubungan antara Pola Asuh Orang Tua dengan Perilaku Seksual Pranikah pada Remaja di SMK Batik 1 Surakarta."

${ }^{22}$ Daniela Veronica Negraia, Jennifer March Augustine, and Kate Chambers Prickett, "Gender Disparities in Parenting Time Across Activities, Child Ages, and Educational Groups," Journal of Family Issues 39, no. 11 (August 19, 2018): 3006-28, https://doi.org/10.1177/0192513X18770232; Hilary F. Byrnes and Brenda A. Miller, "The Relationship between Neighborhood Characteristics and Effective Parenting Behaviors," Journal of Family Issues 33, no. 12 (2012): 1658-87, https://doi.org/ 10.1177/0192513X12437693; Ratih Baiduri and Anggun Yuniar, "Pola Pengasuhan Keluarga Etnis Jawa Hasil Pernikahan Dini di Deli Serdang," Jurnal Antropologi Sumatera 15, no. 1 (2017): 252-58.

${ }^{23}$ Cliff McKinney and Janet W Kwan, "Emerging Adult Perceptions of and Preferences for Parenting Styles and Associated Psychological Outcomes," Journal of Family Issues 39, no. 9 (June 22, 2018): 2491-2504, https://doi.org/10.1177/0192513X18756928; Donna Hoskins, “Consequences of Parenting on Adolescent Outcomes," Societies 4, no. 3 (2014): 506-31, https://doi.org/10.3390/ soc4030506. 
culture can make parents tend to apply authoritative parenting because children's freedom of participation is included in the giving dimension.

The perception of sexuality, gender, and norm in adolescent reproductive health in Patrang District is mostly positive (53.2\%). This study is related to the research of Susanto et $\mathrm{al}^{24}$ which discusses adolescent reproductive health factors, namely gender perceptions and dating activities. The present study revealed that not always adolescent dating has negative perceptions of gender, behavior, and norms in reproductive health. The gender of men who are often assumed to have more sex than women in this study shows their disapproval. They also do not agree if men and women contact each other even though they love each other differently from women who are still in doubt. This reduces the negative stereotypes of men. Thus stereotypes about gender superiority have diminished, men and women have the same roles and responsibilities for their reproductive health as long as they know what is good and what is bad for themselves. When this has been realized, SGNP in reproductive health will also be positive.

Parents with authoritarian and permissive parenting in this study had a low number compared to authoritative parenting. This is related to the results of Lin and Billingham's ${ }^{25}$ research that gender, education level, number of children, and culture in the family can make a difference in parenting. In this study, the proportion of mothers is greater (72.8\%) compared to the proportion of fathers and it is also known that mothers always provide opportunities for children to express their feelings freely when children disagree with mothers. This is different from fathers who rarely allow children to have an opinion. This study is following with Huver et $\mathrm{al}^{26}$ who stated that mothers tend to be authoritative compared to fathers because freedom of opinion is included in the authoritative dimension of giving. Mothers who tend to be authoritative can invite fathers to be more involved in childcare so that parental balance can be realized so that the SGNP of adolescents is positive.

\footnotetext{
${ }^{24}$ Susanto et al., "Prevalence of Factors Related to Active Reproductive Health Behavior: A Cross-Sectional Study Indonesian Adolescent."

${ }^{25}$ Lin and Billingham, "Relationship between Parenting Styles and Gender Role Identity in College Students."

${ }^{26}$ Rose M.E. Huver et al., "Personality and Parenting Style in Parents of Adolescents," Journal of Adolescence 33, no. 3 (2010): 395-402, https://doi.org/10.1016/j.adolescence.2009.07.012.
} 
Based on the description above, parenting parents play an important role in shaping positive SGNP and controlling teenagers in their development. According to Baumrind in the study, Matejevic et al ${ }^{27}$ stated that children of authoritative parents tend to be more socially responsible. SGNP in reproductive health is one that can be used as a control of adolescent behavior. The results of this study are in line with several previous studies ${ }^{28}$ that authoritative parenting can create targeted gender perceptions and in this study, SGNP in adolescent reproductive health is positive. Therefore, proper parenting is expected to place gender well whatever gender stereotypes, women and men have the same position and opportunity, so there is no gap in their care.

Nursing implications that can be applied to parenting parents with gender perceptions, behaviors, and norms in adolescent reproductive health in Patrang District, Jember Regency by paying attention to the role of nurses. First, nurses can invite authoritative parents so that the perception of GPN in adolescent reproductive health is positive regardless of gender differences and without any superiority between male and female genders. As educators, nurses provide information about how parents care for children by not looking at the wrong gender stereotypes, that men are superior to women. As a counselor, nurses provide counseling to overcome problems related to how parents align the roles of men and women in the family so that the SGNP in adolescent reproductive health is positive. This study is limited to the relationship not examining causal causes, so it has not been able to interpret the effects. The reliability of the parenting questionnaire on permissive items is still weak $\mathrm{r}$ $<0.70$ ), so the stability of the data from time to time is inconsistent and needs to be revised again. This research is limited to the sociodemography of parents and adolescents, so other factors still need to be investigated such as the position of the child in the family (youngest or firstborn), whether the gender of the teen sibling is related to the perception of GPN in adolescent reproductive

\footnotetext{
${ }^{27}$ Marina Matejevic, Dragana Jovanovic, and Vesna Lazarevic, "Functionality of Family Relationships and Parenting Style in Families of Adolescents with Substance Abuse Problems," in Procedia - Social and Behavioral Sciences, vol. 128 (2014), 281-87, https://doi.org/10.1016/ j.sbspro.2014.03.157.

${ }^{28}$ Negraia, Augustine, and Prickett, "Gender Disparities in Parenting Time Across Activities, Child Ages, and Educational Groups."
} 
health and caregiving, and more deeply related to ethnicity, gender, number of children related to adolescent gender perceptions.

\section{E. Conclusion}

Based on the results of the study found that parenting parents have a significant relationship with gender perceptions, behavior and norms in adolescent reproductive health $(r=0.193 ; p=0.015)$, besides that authoritative parenting also has a significant relationship with gender perceptions, behaviors and norms in adolescent reproductive health $(\mathrm{r}=0.171 ; \mathrm{p}=0.031$ ). Researchers suggest that parents and adolescents can increase knowledge about reproductive health and appropriate parenting for children. Parents are expected to be able to put gender well whatever gender stereotypes, women and men have the same position and opportunity, avoiding male superiors so that there are no gaps in their care. The next researcher is expected to use other factors such as the position of the child in the family (eldest or youngest), environment, and culture that can be related to the dependent variable, namely gender perception, behavior, and norms in adolescent reproductive health.

\section{F. Acknowledgment}

The researcher would like to thank you to the participants, Jember University Research Institute, Jember Regency Population Office, Patrang District Office, and Faculty of Nursing Universitas Jember. Research Group (KeRis) Family and Health Care Studies, Department of Community Nursing, Family, and Gerontik, Faculty of Nursing, Universitas Jember for being involved in paying research at KeRis.[s]

\section{References}

Baiduri, Ratih, and Anggun Yuniar. "Pola Pengasuhan Keluarga Etnis Jawa Hasil Pernikahan Dini di Deli Serdang." Jurnal Antropologi Sumatera 15, no. 1 (2017): 252-58.

Black, M. C., K. C. Basile, M. J. Breiding, S. G. Smith, M. L. Walters, M. T. Merrick, J. Chen, and M. R. Stevens. The National Intimate Partner and Sexual Violence Survey: 
2010 Summary Report. Atlanta, GA: National Center for Injury Prevention and Control, Centers for Disease Control and Prevention, 2011.

Bongardt, Daphne van de, Hanneke de Graaf, Ellen Reitz, and Maja Deković. "Parents as Moderators of Longitudinal Associations Between Sexual Peer Norms and Dutch Adolescents' Sexual Initiation and Intention." Journal of Adolescent Health 55, no. 3 (2014): 388-93. https://doi.org/10.1016/j.jadohealth.2014.02.017.

Byrnes, Hilary F., and Brenda A. Miller. "The Relationship between Neighborhood Characteristics and Effective Parenting Behaviors." Journal of Family Issues 33, no. 12 (2012): 1658-87. https://doi.org/10.1177/0192513X12437693.

Fleming, Paul J., and Christine Agnew-Brune. "Current Trends in the Study of Gender Norms and Health Behaviors." Current Opinion in Psychology 5, no. 2 (2015): 7277. https://doi.org/10.1016/j.copsyc.2015.05.001.

Hoskins, Donna. "Consequences of Parenting on Adolescent Outcomes." Societies 4, no. 3 (2014): 506-31. https://doi.org/10.3390/soc4030506.

Huver, Rose M.E., Roy Otten, Hein de Vries, and Rutger C.M.E. Engels. "Personality and Parenting Style in Parents of Adolescents." Journal of Adolescence 33, no. 3 (2010): 395-402. https://doi.org/10.1016/j.adolescence.2009.07.012.

Kibtyah, Maryatul. "Peran Konseling Keluarga Dalam Menghadapi Gender Dengan Segala Permasalahannya." Sawwa: Jurnal Studi Gender 9, no. 2 (2017): 361-80. https://doi.org/10.21580/sa.v9i2.641.

Labrague, Leodoro J., Roldan John P. Larios, Karisha E. Cinco, Josephine B. Pescos, Jessica Anne L. Eclipse, Rosalie Ann L. Eclipse, and Vincent C. Laureta. "Future Educators' Gender Norms, Sexuality, and Reproductive Health." Online Journal of Health and Allied Sciences 11, no. 4 (2012): 1-6.

Lefkowitz, Eva S., Cindy L. Shearer, Meghan M. Gillen, and Graciela EspinosaHernandez. "How Gendered Attitudes Relate to Women's and Men's Sexual Behaviors and Beliefs." Sexuality \& Culture 18, no. 4 (2014): 833-46. https:// doi.org/10.1007/s12119-014-9225-6.

Lin, Yi-Ching, and Robert E. Billingham. "Relationship between Parenting Styles and Gender Role Identity in College Students." Psychological Reports 114, no. 1 (2014): 250-71. https://doi.org/10.2466/21.09.PR0.114k13w4.

Maryatun, Maryatun, and Nurul Farimah Nurul Hidayah. "Hubungan antara Pola Asuh Orang Tua dengan Perilaku Seksual Pranikah pada Remaja di SMK Batik 1 Surakarta." Gaster: Jurnal Kesehatan 10, no. 2 (2013): 53-61. 
Matejevic, Marina, Dragana Jovanovic, and Vesna Lazarevic. "Functionality of Family Relationships and Parenting Style in Families of Adolescents with Substance Abuse Problems." In Procedia - Social and Behavioral Sciences, 128:281-87, 2014. https://doi.org/10.1016/j.sbspro.2014.03.157.

McKinney, Cliff, and Janet W Kwan. "Emerging Adult Perceptions of and Preferences for Parenting Styles and Associated Psychological Outcomes." Journal of Family Issues 39, no. 9 (2018): 2491-2504. https://doi.org/10.1177/ $0192513 X 18756928$.

Mohta, Akanksha, Prasanta Kumar Roy, and Pradeep Kumar Saha. "A Study on Perceived Parenting Style among Transgender." Open Journal of Psychiatry \& Allied Sciences 8, no. 2 (2017): 157. https://doi.org/10.5958/23942061.2017.00014.3.

Negraia, Daniela Veronica, Jennifer March Augustine, and Kate Chambers Prickett. "Gender Disparities in Parenting Time Across Activities, Child Ages, and Educational Groups.” Journal of Family Issues 39, no. 11 (2018): 3006-28. https://doi.org/10.1177/0192513X18770232.

Rolleri, LA. "Gender Norms and Sexual Health Behaviors." Research FACTS and Findings., 2013, 1-7.

Sumiatin, Titik, Hadi Purwanto, and Wahyu Tri Ningsih. "Pengaruh Persepsi Remaja tentang Perilaku Seks terhadap Niat Remaja dalam Melakukan Perilaku Seks Beresiko." Jurnal Keperawatan 8, no. 1 (2017): 96-101.

Susanto, Tantut, Iis Rahmawati, and Wantiyah Wantiyah. "A Community-Based Friendly Health Clinic: An Initiative Adolescent Reproductive Health Project in the Rural and Urban Areas of Indonesia." International Journal of Nursing Sciences 3, no. 4 (2016): 371-78. https://doi.org/10.1016/j.ijnss.2016.11.006.

- _ - "Pengaruh Visualisation in Participatory Program (VIPP) dan Metode Ceramah terhadap Pengetahuan, Sikap, dan Keterampilan Kesehatan Reproduksi Remaja di Jember." Jurnal Kesehatan Reproduksi 8, no. 2 (2017): 119-29. https://doi.org/10.22435/kespro.v8i2.5753.119-129.

Susanto, Tantut, Iis Rahmawati, Emi Wuri Wuryaningsih, Ruka Saito, Syahrul Syahrul, Rumiko Kimura, Akiko Tsuda, Noriko Tabuchi, and Junko Sugama. "Prevalence of Factors Related to Active Reproductive Health Behavior: A Cross-Sectional Study Indonesian Adolescent." Epidemiology and Health 38 (2016): e2016041. https://doi.org/10.4178/epih.e2016041. 
Eka Aprilia Wulandari, Tantut Susanto, Kholid Rosyidi Muhammad Nur

Wamoyi, Joyce, Daniel Wight, and Pieter Remes. "The Structural Influence of Family and Parenting on Young People's Sexual and Reproductive Health in Rural Northern Tanzania." Culture, Health \& Sexuality 17, no. 6 (2015): 718-32. https://doi.org/10.1080/13691058.2014.992044.

World Health Organization. "Adolescents: Health Risks and Solutions." World Health Organization, 2018. https://www.who.int/news-room/fact-sheets/detail/ adolescents-health-risks-and-solutions.

- "Global Health Observatory (GHO) Data: Violence Against Women.” World Health Organization, 2015. https://www.who.int/gho/women_and_health/ violence/en/. 